\title{
Effect of green manure amendment and flooding on methane emission from paddy fields
}

\author{
Shang-Shyng Yang *, Hsiu-Lan Chang \\ Department of Agricultural Chemistry, National Taiwan University, Taipei 10617, Taiwan, ROC
}

Received 5 April 1999; accepted 14 March 2000

\begin{abstract}
The effect of green manure amendment, flooding treatment and crop season on methane emission from paddy fields in Taiwan was investigated from August 1994 to July 1996. Sesbania amendment stimulated methane emission and the effect was more significant at the early growth stage of rice. Methane emission was higher in continuous flooding treatment than that in intermittent irrigation. Both redox potential and methane emission showed significant differences between these two irrigation systems. Methane concentration increased sharply with the depth of soil in the intermittent irrigation system due to oxidation; whereas it increased moderately in the continuous flooding treatment. The seasonal methane flux in the first crop season with chemical fertilizer was between 2.73 and $5.23 \mathrm{~g} \mathrm{~m}^{-2}$; while the value was between 10.54 and $10.56 \mathrm{~g} \mathrm{~m}^{-2}$ in the second crop season. In the case of Sesbania amendment in the second crop season, the seasonal methane flux in the first crop season was $6.35 \mathrm{~g} \mathrm{~m}^{-2}$; while the value was between 14.43 and $30.12 \mathrm{~g} \mathrm{~m}^{-2}$ in the second crop season. Total methane emission in the second crop season was about two to five-fold higher than that in the first crop season. (c) 2000 Elsevier Science Ltd. All rights reserved.
\end{abstract}

Keywords: Methane emission; Paddy field; Manure amendment; Intermittent irrigation; Continuous flooding

\section{Introduction}

Currently, methane has a global average mixing ratio of about $1.72 \mu \mathrm{g} \mathrm{cm}^{-3}$ in the troposphere. The major sources are from rice paddies, wetlands, sediments, animal wastes and landfills (Watson et al., 1992; Watanabe et al., 1993; Yang et al., 1994; Yang, 1998; Yang and Chang, 1998). Methane is produced by a group of strict anaerobic bacteria in highly reduced environment (Whitman et al., 1982). More than $80 \%$ of the methane produced is oxidized to carbon dioxide in the overlying water (Rudd and Hamilton, 1979; Holzapfel-Pschorn et al., 1985). However, methane produced in paddy soil

\footnotetext{
${ }^{*}$ Corresponding author. Tel.: +886-2-2362-1519; fax: +8862-2367-9827.

E-mail address: ssyang@ccms.ntu.edu.tw (S.-S. Yang).
}

is emitted directly to the atmosphere and oxidized only partially prior to reaching the atmosphere (Cicerone et al., 1983).

Rice is the major crop in Taiwan. The cultivation area was 202,010 ha for the first crop season and 162,202 ha for the second crop season in 1997. In the previous studies, it was found that methane emission from the first crop season of paddy rice in pot cultivation with continuous flooding was higher than that in the second crop season (Yang et al., 1994; Yang and Chang, 1997). This result was reversed in the practical paddy fields with intermittent irrigation from the late active tillering stage to the ripening stage (Yang and Chang, 1999). In addition, methane flux was affected markedly with straw application, soil type, rice plant and by environmental conditions (Yang et al., 1994; Yang and Chang, 1997, 1998). Gilbert and Frenzel (1995) and Buendia et al. (1998) also indicated that methane flux fluctuates 
markedly with environmental conditions, nutrients and the presence of rice plants.

The effect of crop seasons, water management, green manure amendment, location, and rice variety on methane emission from paddy fields was investigated. We chose two locations, four crop seasons, two water managements, two fertilizer applications and three varieties to measure methane emission from local paddy fields in Taiwan.

\section{Materials and methods}

\subsection{Site description and agricultural practices}

Paddy fields of the Agricultural Experimental Station of National Taiwan University (NTU) $\left(25^{\circ} 02^{\prime} \mathrm{N}\right.$, $120^{\circ} 31^{\prime} \mathrm{E}$ ) located in Taipei City and Taoyuan District Agricultural Improvement Station $\left(25^{\circ} 01^{\prime} \mathrm{N}, 121^{\circ} 02^{\prime} \mathrm{E}\right)$ located in Taoyuan County were selected as test paddy fields.

Two irrigation practices were compared: continuous flooding, where a $5 \mathrm{~cm}$ water depth was maintained throughout the growing season; and intermittent irrigation, where the field was flooded while the rice plants become established, then allowed to drain, re-irrigation only after the soil starts to dry. Green manure (Sesbania sp.) was cultivated on a sample field between the first and second rice crops during 1994 and 1995, then incorporated into the soil before the field was transplanted. Properties and agricultural practices of test paddy fields are listed in Tables 1 and 2. All experiments were performed in quadruplicate.

\subsection{Gas sampling chamber}

The duration of measurement was recommended from the previous studies of Holzapfel-Pschorn and Seiler (1986) for 1-2 h, Schutz et al. (1989) for $1 \mathrm{~h}$, and Chang and Yang (1997) for $15 \mathrm{~min}$ to $2 \mathrm{~h}$. There was a linear correlation between methane concentration and accumulative time $\left(r^{2}=0.99\right)$. Methane emission rates were in same levels and they had not significant differences among the accumulative time from $15 \mathrm{~min}$ to $2 \mathrm{~h}$. Therefore, we used closing interval of $0.5 \mathrm{~h}$ to measure methane emission from paddy fields. Gas samples were collected using a home-made acrylic chamber (length 40 $\mathrm{cm}$, width $40 \mathrm{~cm}$ and height $65 \mathrm{~cm}$, about 961 ) that was equipped with an electric fan, a thermometer and a sampling hole covered with a rubber septum. In the later growth stage of paddy rice, a two-layer acrylic chamber was used (height $130 \mathrm{~cm}$, about 192 1). Four hills per chamber (each hill contained four plants and spacing of hill was $24 \times 27 \mathrm{~cm}$ ) were measured and four

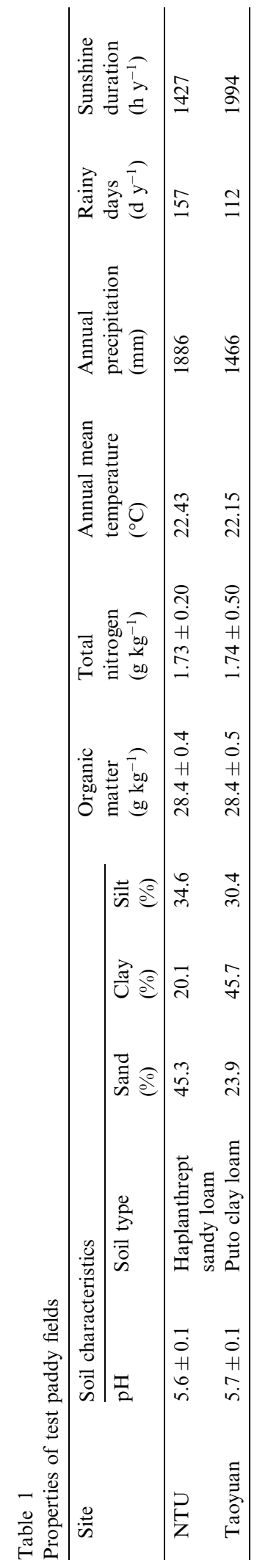


S.-S. Yang, H.-L. Chang / Chemosphere - Global Change Science 3 (2001) 41-49

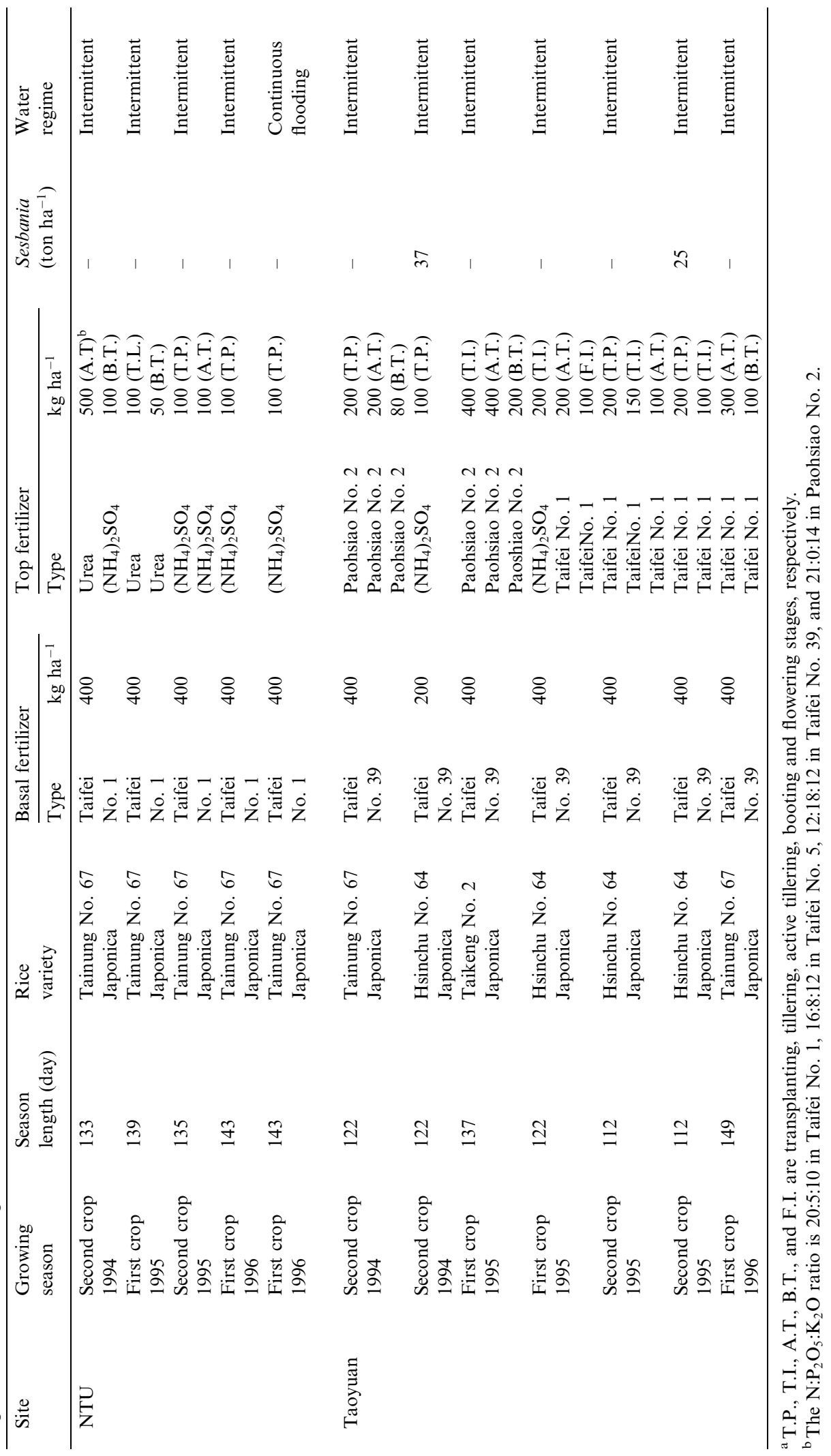


chambers were used in each measurement (Chang and Yang, 1997). The chamber was put in the soil with 2-3 $\mathrm{cm}$ depth for $10 \mathrm{~min}$ equilibrium to reduce the disturbance of sample site during the measurement. Gas samples were also collected with a hemisphere glass chamber (diameter $9 \mathrm{~cm}, 500 \mathrm{ml}$ ) that had a sampling hole covered with a rubber septum on the top. Glass chamber was covered on the soil between the hill and put in the soil with $2-3 \mathrm{~cm}$ depth for 10 min equilibrium. Four glass chambers were used in each experiment to measure the methane emission from paddy soil without rice plants.

\subsection{Gas sampling period and method}

Six sampling stages, during the flooding to transplanting, active tillering, booting, flowering, ripening and fallow, were chosen in each crop season. Gas samples were collected at 0,30 and $60 \mathrm{~min}$ accumulative time using the gas dilution method. The air temperature increased $2-3^{\circ} \mathrm{C}$ during $1 \mathrm{~h}$ closure in the day-time and it increased $0-0.5^{\circ} \mathrm{C}$ at night. $5 \mathrm{ml}$ of gas was withdrawn first by a $10 \mathrm{ml}$ disposable plastic syringe from a $12 \mathrm{ml}$ serum bottle that had been sealed with a butyl rubber stopper and flushed with oxygen-free nitrogen gas. Then another $5 \mathrm{ml}$ of the gas sample from the sampling chamber was injected into a serum bottle (Chang and Yang, 1997).

\subsection{Methane production}

A soil core $(15.0 \mathrm{~cm}$ length) from the top to $20 \mathrm{~cm}$ depth was obtained from the experimental rice field. Each $5.0 \mathrm{~cm}$ length of soil (diameter $1.12 \mathrm{~cm}$ ) was put into a $50 \mathrm{ml}$ serum bottle which had been previously flushed with oxygen-free nitrogen gas and sealed with a butyl rubber stopper. After shaking, the gas $(1.0 \mathrm{ml})$ in the head space was withdrawn and $0.3 \mathrm{ml}$ was injected into gas chromatography for methane determination.

\subsection{Methane emission}

Methane emission was determined at a $0.5 \mathrm{~h}$ intervals for $1.0 \mathrm{~h}$ by measuring the changes of methane concentration (the net change between methane emission and sink) in the acrylic chamber. The gas sample was injected onto a Shimadzu 14 A gas chromatograph (Shimadzu, Japan) with a glass column $(2.6 \mathrm{~mm} \times$ $2.0 \mathrm{~m}$ ) which was packed with Porapak Q (80/100 mesh). The column temperature was set at $100^{\circ} \mathrm{C}$, and the injection and the detector temperatures were set at $130^{\circ} \mathrm{C}$. The methane concentration was calculated from a standard curve from 0.1 to $1000 \mathrm{mg} \mathrm{kg}^{-1}$ (vol) (Chang and Yang, 1997).

\subsection{Estimation of methane emission}

Methane emission from paddy field is calculated from the experimental data and estimated by the following equation (Rolston, 1986):

$f=(V / A)(\Delta C / \Delta t)$,

where $f$ is the methane emission rate $\left(\mathrm{mg} \mathrm{m}^{-2} \mathrm{~h}^{-1}\right), V$ the volume of chamber above soil $\left(\mathrm{m}^{3}\right), A$ the cross-section of chamber $\left(\mathrm{m}^{2}\right), \Delta C$ the concentration difference between zero time and time $t\left(\mathrm{mg} \mathrm{m}^{-3}\right)$, and $\Delta t$ is the time duration between the two sampling periods $(h)$. The total methane emission from the paddy field is the summation of methane emission in six growth stages of rice plants.

\subsection{Analytical methods}

Redox potential was measured directly with a Hanna No. 081-854 potential meter (Code HI 8424) under 5-20 $\mathrm{cm}$ depth of topsoil using the Pt electrode for 20-25 min equilibrium with the soil (Chang and Yang, 1997). Soil $\mathrm{pH}$ was determined directly in the field or on 1:1 (w/w) soil to water suspension with a $\mathrm{pH}$ meter (Mode Sentron 2001). Light intensity was measured with a Toshiba SPI-5 photometer. Temperature was determined with a thermometer. Experiments were carried out to obtain four measurements and flux data subjected to analysis of variance and Duncan's multiple range test $(P=0.05)$ using the SAS (1988).

\section{Results}

\subsection{Growth of rice plant}

Total growth period of paddy rice in the first crop season (February-July) was between 122 and 149 days, and it ranged from 112 to 135 days in the second crop season (August-December) (Table 2). Effect of agricultural management and rice varieties on total growth period was slight. The daily soil temperature increased during cultivation in the first crop season (from $13^{\circ} \mathrm{C}$ to $32^{\circ} \mathrm{C}$ ) and decreased in the second crop season (from $33^{\circ} \mathrm{C}$ to $14^{\circ} \mathrm{C}$ ). The soil temperature was between $15.2^{\circ} \mathrm{C}$ and $19.4^{\circ} \mathrm{C}$ at the transplanting stage and between $26.9^{\circ} \mathrm{C}$ and $29.6^{\circ} \mathrm{C}$ at the ripening stage in the first crop season. While in the second crop season, the soil temperature ranged from $26.8^{\circ} \mathrm{C}$ to $29.9^{\circ} \mathrm{C}$ at the transplanting stage and ranged from $16.4^{\circ} \mathrm{C}$ to $23.1^{\circ} \mathrm{C}$ at the ripening stage. The annual mean temperatures were very similar in both test paddy fields. However, the annual precipitation and the rainy days were high in NTU paddy field, while sunshine duration was high in Taoyuan paddy field. 


\subsection{Green manure amendment and methane emission}

During the fallow period between the first season harvest and the second crop seasons planting, green manure was cultivated and then dug into the soil for organic fertilizer before the next crop season in Taoyuan paddy field. The effect of green manure amendment on methane emission is shown in Table 3. Sesbania amendment stimulated methane emission from the paddy field. Application of 37 tons ha ${ }^{-1}$ of fresh Sesbania increased methane emission 2.85-fold in the second crop season of 1994, while the stimulatory effect was only 1.37-fold in the second crop season of 1995 for another 25 tons $\mathrm{ha}^{-1}$ of fresh Sesbania amendment.

The effect of green manure amendment on methane emission was more significant at the early growth stage of rice and decreased gradually during cultivation. Methane emission rate at the transplanting stage was 1.35-5.48 times of those chemical fertilizer application only and they had significant difference between them, while the values were not significantly different from the flowering to the ripening stages. Seasonal methane emission with green manure amendment was between 6.35 and $30.12 \mathrm{~g} \mathrm{~m}^{-2}$, and the values with chemical fertilizer application ranged from 2.73 to $10.56 \mathrm{~g} \mathrm{~m}^{-2}$ (Table 3). Sesbania amendment also increased soil organic matter content. After rice harvest, the soil organic matter content was $35.9 \pm 2.0 \mathrm{~g} \mathrm{~kg}^{-1}$ and $31.7 \pm 1.5 \mathrm{~g}$ $\mathrm{kg}^{-1}$ in the second crop season of 1994 and 1995, respectively. However, the organic matter content was only $28.4 \pm 0.4$ and $26.2 \pm 0.5 \mathrm{~g} \mathrm{~kg}^{-1}$ in the paddy field treated with chemical fertilizer only, respectively.

\subsection{Agricultural practice and methane emission}

Effect of flooding treatment on methane emission and redox potential in the second crop season of NTU paddy field is presented in Fig. 1. Redox potential increased gradually with intermittent irrigation during rice cultivation and the value remained constant with continuous flooding during rice cultivation before 1 week for harvest. Methane emission was $15.27 \pm 1.46 \mathrm{~g} \mathrm{~m}^{-2}$ with intermittent irrigation and it was $28.85 \pm 3.25 \mathrm{~g} \mathrm{~m}^{-2}$ with continuous flooding. The average methane emission rate was $5.39 \pm 0.56$ and $9.54 \pm 1.07 \mathrm{mg} \mathrm{m}^{-2} \mathrm{~h}^{-1}$, respectively. Methane emission rate was high at the transplanting stage, decreasing very sharply at the active tillering stage and low at the flowering and the ripening stages with intermittent irrigation. However, methane emission rate was high at both the transplanting and the booting stages and decreased gradually at the flowering stage with continuous flooding. Redox potential and methane emission showed significant difference between the intermittent irrigation system and the continuous flooding treatment $(P<0.05)$.

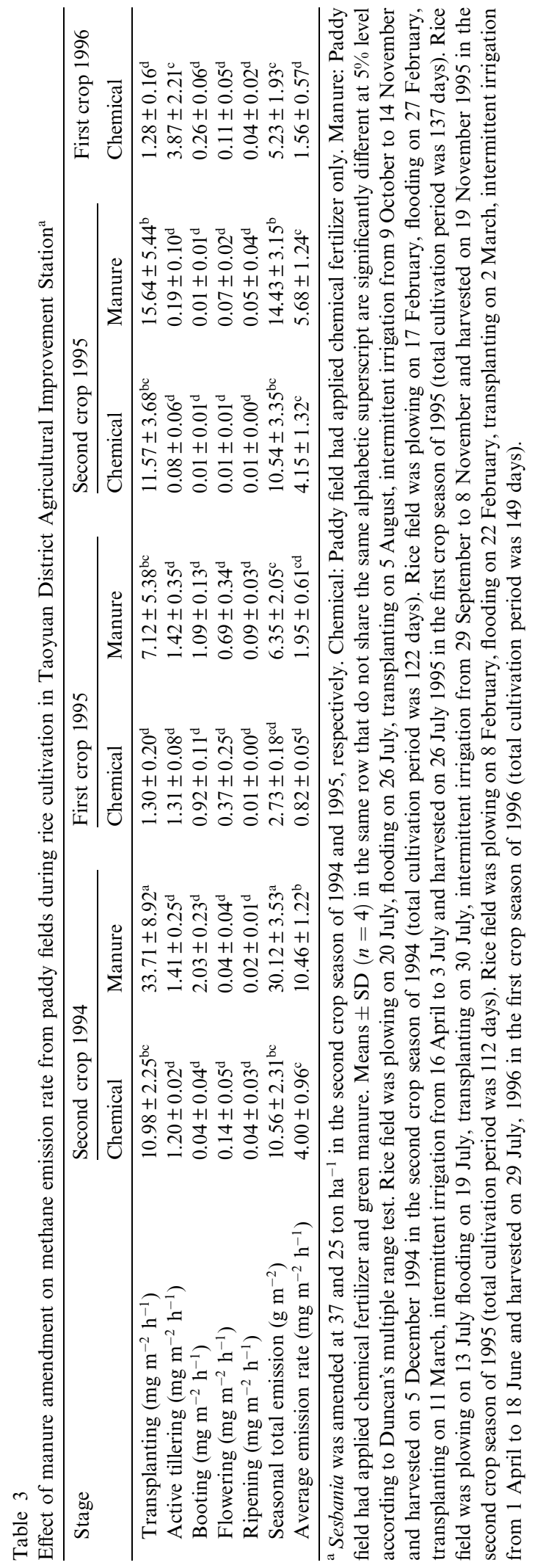




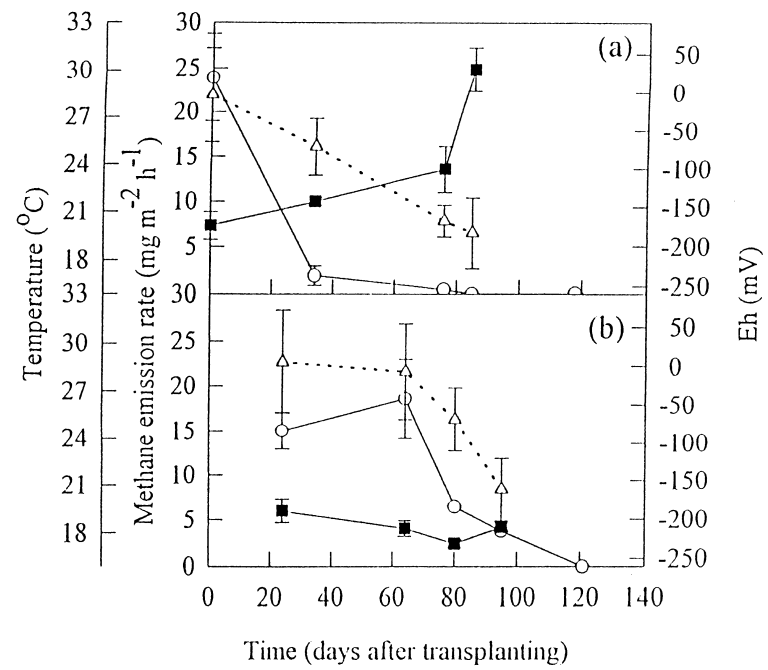

Fig. 1. Effect of water management on methane emission, soil temperature and redox potential in Agricultural Experimental Station of National Taiwan University paddy field in the second crop season 1994 and 1995. (a) With intermittent irrigation in the second crop season 1994. (b) With continuous flooding in the second crop season 1995. $\bigcirc — \bigcirc$ : methane emission rate;

- - redox potential; $\triangle---\triangle$ : soil temperature.

In the first crop season of 1996, the redox potential of intermittent irrigation system and continuous flooding was very similar at the early growth stage of rice, but the value increased at the late growth stage with the intermittent irrigation system, whereas the redox potential remained low with continuous flooding treatment. Methane emission was low at the early growth stage of rice due to the low temperature and it increased sharply at the late growth stage with continuous flooding. However, methane emission was low at the late growth stage with the intermittent irrigation system (Fig. 2). Both redox potential and methane emission also showed significant difference between these two irrigation systems $(P<0.05)$.

\subsection{Effect of rice plants on methane emission}

Methane concentration in the paddy soil with intermittent irrigation increased from $1.85 \pm 1.05 \mathrm{mg} \mathrm{m}^{-3}$ at $0-5 \mathrm{~cm}$ depth to $79.63 \pm 8.08 \mathrm{mg} \mathrm{m}^{-3}$ at $10-15 \mathrm{~cm}$ depth. Whereas the value increased only from $51.85 \pm 3.05 \mathrm{mg}$ $\mathrm{m}^{-3}$ at $0-5 \mathrm{~cm}$ depth to $89.63 \pm 8.08 \mathrm{mg} \mathrm{m}^{-3}$ at $10-15$ $\mathrm{cm}$ depth with continuous flooding (Table 4).

Effect of the presence of rice plants on methane emission from the paddy field was low at the early growth stage due to the small size of the plants. The difference of methane emission from paddy field and from paddy soil (without rice plants) was not significant $(P>0.05)$ [Figs. 3(a) and (c)]. During cultivation of the second crop, the temperature decreased and the redox

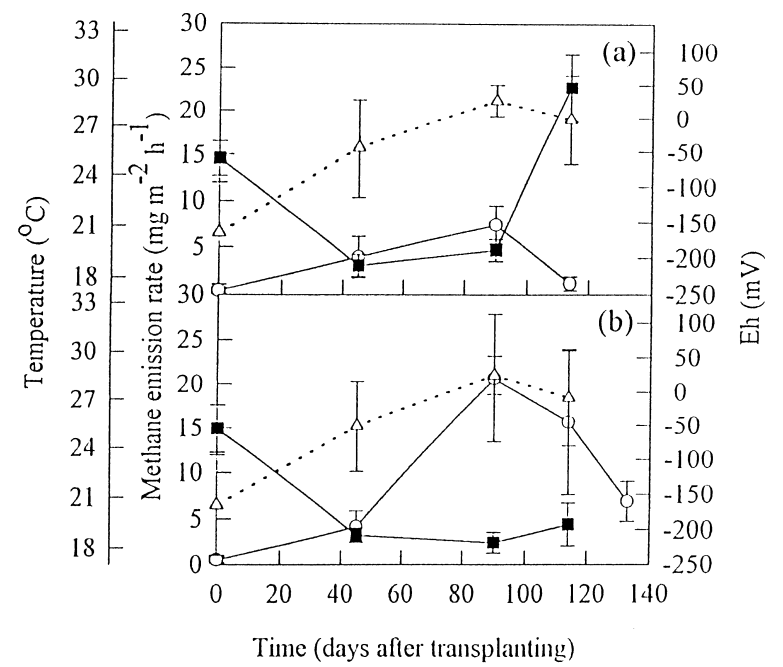

Fig. 2. Effect of water management on methane emission, soil temperature and redox potential in Agricultural Experimental Station of National Taiwan University paddy field in the first crop season 1995. (a) With intermittent irrigation. (b) With continuous flooding. $\bigcirc-\bigcirc$ : methane emission rate; redox potential; $\triangle---\triangle$ : soil temperature.

Table 4

Effect of irrigation system on methane concentration in paddy soil $^{\text {a }}$

\begin{tabular}{lll}
\hline $\begin{array}{l}\text { Soil depth } \\
(\mathrm{cm})\end{array}$ & $\begin{array}{l}\text { Intermittent } \\
\text { irrigation } \\
\left(\mathrm{mg} \mathrm{m}^{-3}\right)\end{array}$ & $\begin{array}{l}\text { Continuous } \\
\text { flooding } \\
\left(\mathrm{mg} \mathrm{m}^{-3}\right)\end{array}$ \\
\hline $0-5$ & $1.85 \pm 1.05^{\mathrm{d}}$ & $51.85 \pm 3.05^{\mathrm{b}}$ \\
$5-10$ & $33.85 \pm 5.46^{\mathrm{c}}$ & $73.47 \pm 5.46^{\mathrm{a}}$ \\
$10-15$ & $79.63 \pm 8.08^{\mathrm{a}}$ & $89.63 \pm 8.08^{\mathrm{a}}$ \\
\hline
\end{tabular}

${ }^{a}$ Surface soil was dry for intermittent irrigation and there was $5 \mathrm{~cm}$ depth of flooding water on surface soil for continuous flooding. Sampling time was at the flowering stage in the first crop season at NTU paddy field. Means \pm SD $(n=4)$ in the same column that did not share the same alphabetic superscript were significantly different at 5\% level according to Duncan's multiple range test.

potential increased for the practice with intermittent irrigation. Methane emission decreased with the growth of rice plants, and effect of the presence of rice plants on methane emission was low at the late growth stage. While in the first crop season, the effect of rice plant on methane emission was also not significant at the early growth stage because of the small size of the plants and the low temperature. The difference increased with the rice cultivation as the plants increased in size and the temperature rose [Figs. 3(b) and (d)]. Methane emission was significantly different $(P<0.05)$ at the late growth stage between them. Methane production was very active at high temperature, and most of methane remained in the paddy soil because of the high oxidative envi- 


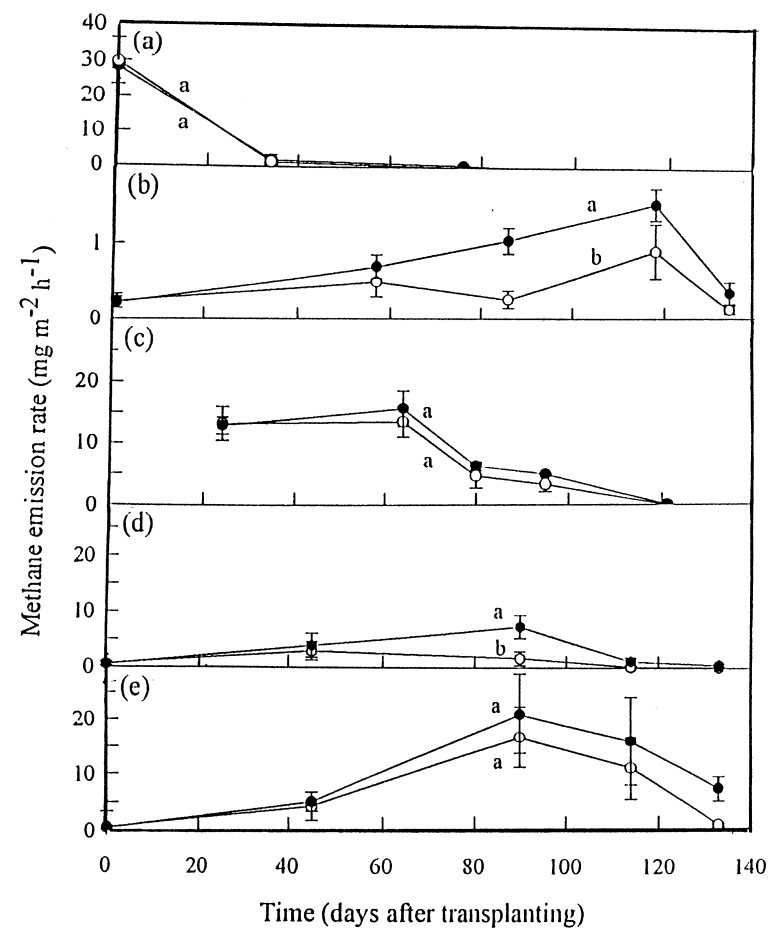

Fig. 3. Effect of the presence of rice plants on methane emission from the paddy field during rice cultivation in Agricultural Experimental Station of National Taiwan University. (a) The second crop season 1994 with intermittent irrigation. (b) The first crop season 1995 with intermittent irrigation. (c) The second crop season 1995 with intermittent irrigation. (d) The first crop season 1996 with intermittent irrigation. (e) The first crop season 1996 with continuous flooding. - o in the presence of rice plants; $\bigcirc — \bigcirc$ : without rice plants.

ronment and the low diffusion rate in the soil surface. However, the effect of the presence of rice plant on methane emission from the paddy field with continuous flooding was not significant $(P>0.05)$ [Fig. 3(e)]. This result might be due to the high reducing environment in the paddy field and most of methane produced in the paddy field being emitted to the atmosphere by diffusion through the soil or by bubbling into the water. Methane emission from rice plant with intermittent irrigation was between $74.3 \%$ and $77.4 \%$ of methane production at the booting stage and $40.41 \%$ at the flowering stage. Methane emission from rice plant with continuous flooding $(20.38 \%)$ was lower than that with intermittent irrigation (Table 5).

Seasonal methane emission was between 2.73 and $5.23 \mathrm{~g} \mathrm{~m}^{-2}$ in the first crop season, and between 13.7 and $28.9 \mathrm{~g} \mathrm{~m}^{-2}$ in the second crop season with intermittent irrigation. Total methane emission was between 5252 and 23,634 tons for 202,010 ha paddy fields in the first crop season of 1997, and it was between 22,222 and 47,114 tons for 162,202 ha paddy fields in the second crop season. Annual methane emission from paddy fields was between 27,474 and 70,748 tons with intermittent irrigation in Taiwan. In the case of continuous flooding, seasonal methane emission was 32.65 $\mathrm{g} \mathrm{m}^{-2}$ in the first crop season, and the value was $28.85 \mathrm{~g}$ $\mathrm{m}^{-2}$ in the second crop season. Annual methane emission was 112,751 tons. Methane emission from paddy field reduced significantly with intermittent irrigation in Taiwan.

\section{Discussion}

There are two crop seasons for paddy rice in Taiwan. The growth period of the first crop season was longer than the second crop season due to the low temperature in the first crop season (mean temperature $21.58^{\circ} \mathrm{C}$ vs. $23.87^{\circ} \mathrm{C}$ ). The growth period of rice depends mainly on crop season, and the effect of variety, fertilizer application and agricultural management was less. The daily temperature patterns are different between these two crop seasons. Daily temperature increases during the cultivation in the first crop season and it falls in the second one. This is different from the single crop season countries such as Japan, Korea, USA and Italy (Holzapfel-Pschorn and Seiler, 1986; Sass et al., 1990; Yagi and Minami, 1990; Shin et al., 1995). Therefore, the methane emission patterns of the two crop seasons in Taiwan were also different to other locations with single crop season. Methane emission was high at the

Table 5

Effect of the presence of rice plants on methane emission from paddy fields

\begin{tabular}{lllccc}
\hline Location & Crop season & Growth stage & $\begin{array}{l}\text { With rice plant } \\
(A)^{\mathrm{a}}\left(\mathrm{mg} \mathrm{m}^{-2}\right)\end{array}$ & $\begin{array}{l}\text { Without rice plant } \\
(B)^{\mathrm{b}}\left(\mathrm{mg} \mathrm{m}^{-2}\right)\end{array}$ & $\begin{array}{l}\text { Emission ratio } \\
(A-B / A)(\%)\end{array}$ \\
\hline NTU & First crop 1995 & Booting & $1.01 \pm 0.16$ & $0.26 \pm 0.12$ & 74.26 \\
& & Flowering & $1.46 \pm 0.20$ & $0.87 \pm 0.34$ & 40.41 \\
NTU & First crop 1996 & Booting & $7.43 \pm 2.06$ & $1.68 \pm 1.09$ & 77.39 \\
NTU $^{c}$ & First crop 1996 & Booting & $20.71 \pm 1.19$ & $16.49 \pm 5.68$ & 20.38 \\
\hline
\end{tabular}

\footnotetext{
${ }^{a}$ Methane emission was measured by acrylic chamber method with four hills of rice plants.

${ }^{\mathrm{b}}$ Methane emission was determined by glass chamber method without rice plants.

${ }^{\mathrm{c}}$ Continuous flooding.
} 
transplanting stage in the second crop season and at the booting stage in the first crop season.

Green manure amendment stimulated methane emission rate and it also increased the soil organic matter content. Similar results were also found in rice pot cultivation of Taiwan (Yang and Chang, 1997), dry and wet crop seasons in the Philippines paddy field (Denier and Neue, 1995). The soil organic matter content increased with the amount of applied organic matter (Wassmann et al., 1996). In addition, the stimulatory effect of organic matter amendment depended on the component and the depth of the applications. Methane emission increased 12-fold with 10-12 cm depth application of organic matter, and the value was only 6 -fold with application in $0-10 \mathrm{~cm}$ depth (Delwiche and Cicerone, 1993). Methane emission enhanced 3.10-5.05 times with the application of compost to the application of chemical fertilizer (Yang and Chang, 1997, 1998).

There are three major stages for methane emission from paddy soil, the addition of external organic matter, the booting and the flowering stages (Yagi and Minami, 1990; Yang et al., 1994; Denier and Neue, 1995; Shin et al., 1995). Therefore, high methane emission from paddy field at the early growth stage is due to the addition of external organic substances and the anaerobic digestion of organic matter. The high methane emission at the later stage was due to the active rice growth and the abundance of root secretions as the substrate for methane production (Schutz et al., 1989; Yagi and Minami, 1990; Lindau et al., 1993; Denier and Neue, 1995; Shin et al., 1995). However, methane emission was low at the late growth stage with intermittent irrigation because high soil redox potential does not favor methane production. Therefore, methane emission from paddy fields in the first crop season was lower than that in the second crop season with intermittent irrigation, the reverse was true in the pot cultivation or in the paddy field with continuous flooding (Yang and Chang, 1997, 1999).

Continuous flooding is the traditional method for rice cultivation. There is $10-15 \mathrm{~cm}$ depth of flooding in the soil surface during the rice cultivation in Italian, Louisiana and California paddy fields (Cicerone et al., 1983; Schutz et al., 1989; Lindau et al., 1993). However, the intermittent irrigation system is very popular in the late stage of paddy rice cultivation in Taiwan to reduce the water resource for rice growth, to increase the rice yield and to eliminate toxic substances in the rice root. Mishra et al. (1997) indicated that a paddy field treated with non-flooding, flooding and non-flooding had a significantly higher grain yield than alternating moisture treatments. The accumulative methane emission was around $70 \%$ lower with intermittent irrigation than with continuously flooded treatment. Yagi and Minami (1990) reported that mid-summer drainage of paddy fields could provide the oxygen for root respiration, re- move the organic acids and reduce the methane emission. Similar phenomena were also indicated by Mishra et al. (1997), van Breeman and Feijtel (1990) and Conrad and Rothfuss (1991). Seasonal methane emission in the first crop season was lower than that in the second crop season with intermittent irrigation at the late growth stage of rice. Annual methane emission from paddy fields was between 27,474 and 70,748 tons with intermittent irrigation in Taiwan. However, the value was 112,751 tons with continuous flooding. Methane emission factor was 4.804 and $5.584 \mathrm{~kg} \mathrm{ha}^{-1} \mathrm{~d}^{-1}$ in the first and the second crop season in Taiwan with IPCC method, respectively. Total methane emission was 126,160 and 115,028 tons in the first and the second crop seasons, respectively. Annual methane emission was 241,188 tons. Therefore, total methane emission from paddy fields in Taiwan using an intermittent irrigation system was lower than that measured with continuous flooding or estimated by the IPCC method with continuous flooding. An intermittent irrigation system for paddy fields can reduce the water consumption in rice cultivation and mitigate methane emission in agriculture production.

\section{Acknowledgements}

The authors thank Professors H.C. Lin, Y.S. Wang and C.M. Lai for their technical assistance and helpful comments, and the National Science Council of the Republic of China for financial support (NSC 84-2621P002-033, NSC 85-2621-P002-016 and NSC 86-2621P002-004).

\section{References}

Buendia, L.V., Neue, H.U., Wassmann, R., Lantin, R.S., Javellana, A.M., Arah, J., Wang, Z., Wanfang, L., Makarim, A.K., Corton, T.M., Charoensilp, N., 1998. An efficient sampling strategy for estimating methane emission from rice field. Chemosphere 36, 395-407.

Chang, H.L., Yang, S.S., 1997. Measurement of methane emission from soil. J. Chin. Agric. Chem. Soc. 35, 475-484.

Cicerone, R.J., Setter, J.D., Delwiche, C.C., 1983. Seasonal variation of methane flux from a California rice paddy. J. Geophys. Res. 88, 11022-11024.

Conrad, R., Rothfuss, F., 1991. Methane oxidation in soil surface layer of a flooded rice field and the effect of ammonium. Biol. Fert. Soils 12, 28-32.

Delwiche, C.C., Cicerone, R.J., 1993. Factors affecting methane production under rice. Global Biogeochem. Cycles 7, 143155.

Denier van der Gon, H.A.C, Neue, H.U., 1995. Influence of organic matter incorporation on the methane emission from a wetland rice field. Global Biogeochem. Cycles 9, $11-22$. 
Gilbert, B., Frenzel, P., 1995. Methanotrophic bacteria in the rhizosphere of rice microcosms and their effect on porewater methane concentration and methane emission. Biol. Fert. Soils 20, 93-100.

Holzapfel-Pschorn, A., Conrad, R., Seiler, W., 1985. Production, oxidation and emission of methane in rice paddies. FEMS Microbiol. Ecol. 31, 343-351.

Holzapfel-Pschorn, A., Seiler, W., 1986. Methane emission during a cultivation period from a Italian rice paddy. J. Geophys. Res. 91, 11803-11814.

Lindau, C.W., Bollich, P.K., DeLaune, R.D., Mosier, A.R., Bronson, K.F., 1993. Methane mitigation in flooded Louisiana rice fields. Biol. Fert. Soils 15, 174-178.

Mishra, S., Rath, A.K., Adhya, T.K., Rao, V.R., Sethunathan, N., 1997. Effect of continuous and alternate water regimes on methane efflux from rice under greenhouse conditions. Biol. Fert. Soils 24, 399-405.

Rolston, D.E., 1986. Gas flux. In: Klute, A. (Ed.), Methods of Soil Analysis, second ed. American Society of Agronomy and Soil Science Society of America, Wisconsin, pp. 11031119.

Rudd, J.W.H., Hamilton, R.D., 1979. Methane cycling in lake 227 in perspective with some components of the carbon and oxygen cycles. Arch. Hydrobiol. Ergbenis. Limnol. 12, 115-122.

SAS Institute, 1988. SAS/STAT User's Guide. Release 6.03 SAS Inst. Cary, North Carolina.

Sass, R.L., Fisher, F.M., Harcombe, P.A., Tuner, F.T., 1990. Methane production and emission in a Texas rice field. Global Biogeochem. Cycles 4, 47-68.

Schutz, H., Holzapfel-Pschorn, A., Conard, R., Rennenberg, H., Seiler, W., 1989. A three-year continuous record on the influence of daytime, season, and fertilizer treatment on methane emission rates from an Italian rice paddy. J. Geophys. Res. 94, 16405-16416.

Shin, Y.K., Lee, Y.S., Yun, S.H., Park, M.E., 1995. Methane emission measurement in rice paddy of Korea. In: Proceedings of International Symposium on Environment and Biometeorology. China Agricultural Scientech Press, Beijing, pp. 495-503. van Breeman, N., Feijtel, T.C.J., 1990. Soil processes and properties involved in the production of greenhouse gases, with special relevance to soil taxonomic systems. In: Bouwman, A.F. (Ed.), Soil and the Greenhouse Effect.Wiley, New York, pp. 195-223.

Wassmann, R., Shangguan, X.J., Tolg, M., Cheng, D.X., Wang, M.X., Papen, H., Rennenberg, H., Seiler, W., 1996. Spatial and seasonal distribution of organic amendments affecting methane emission from Chinese rice fields. Biol. Fert. Soils 22, 191-195.

Watanabe, A., Katoh, K., Kimura, M., 1993. Effect of rice straw application on methane emission from paddy fields. II. Contribution of organic constituents in rice straw. Soil Sci. Plant Nutr. 39, 707-712.

Watson, R.T., Meira Filho, L.G., Sanhueza, E., Janetos, A., 1992. Greenhouse gases: sources and sinks. In: Intergovernmental Panel on Climate Change (IPCC). IPCC Supplement, pp. 29-42.

Whitman, W.B., Ankwanda, E., Wolfe, R., 1982. Nutrition and carbon metabolism of Methanococcus voltae. J. Bacteriol. $149,852-863$.

Yagi, K., Minami, K., 1990. Effects of organic matter applications on methane emission from Japanese paddy fields. In: Bouwman, A.F. (Ed.), Soil and the Greenhouse Effect. Wiley, New York, pp. 467-473.

Yang, S.S., 1998. Methane production of river and lake sediments in Taiwan. Environ. Geochem. Health 18, 245-250.

Yang, S.S., Chang, E.H., 1997. Effect of fertilizer application on methane emission/production in the paddy soils of Taiwan. Biol. Fert. Soils 25, 245-251.

Yang, S.S., Chang, H.L., 1998. Effect of environmental conditions on methane production and emission from paddy soil. Agric. Ecosyst. Environ. 69, 69-80.

Yang, S.S., Chang, H.L., 1999. Diurnal variation of methane emission from paddy fields at different growth stages of rice cultivation in Taiwan. Agric. Ecosyst. Environ. 76, 75-84.

Yang, S.S., Lin, C.C., Chang, E.H., Chung, R.S., Huang, S.N., 1994. Effect of fertilizer, soil type, growth season on methane production and emission in the paddy soils of Taiwan. J. Biomass Energy Soc. China 13, 68-87. 